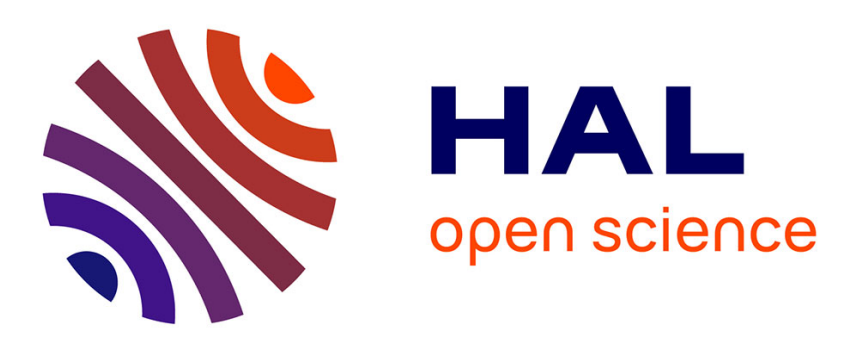

\title{
Kinetic Study of the Temperature Dependence of OH-Initiated Oxidation of n-Dodecane
}

Houssni Lamkaddam, Aline Gratien, Manon Ropion, Edouard Pangui, Jean-François Doussin

\section{- To cite this version:}

Houssni Lamkaddam, Aline Gratien, Manon Ropion, Edouard Pangui, Jean-François Doussin. Kinetic Study of the Temperature Dependence of OH-Initiated Oxidation of n-Dodecane. 2020. hal-02435165

\author{
HAL Id: hal-02435165 \\ https://hal.science/hal-02435165
}

Preprint submitted on 10 Jan 2020

HAL is a multi-disciplinary open access archive for the deposit and dissemination of scientific research documents, whether they are published or not. The documents may come from teaching and research institutions in France or abroad, or from public or private research centers.
L'archive ouverte pluridisciplinaire HAL, est destinée au dépôt et à la diffusion de documents scientifiques de niveau recherche, publiés ou non, émanant des établissements d'enseignement et de recherche français ou étrangers, des laboratoires publics ou privés. 


\section{Kinetic Study of the Temperature Dependence}

\section{of OH-Initiated Oxidation of n-Dodecane}

Houssni Lamkaddam ${ }^{\dagger,}$, Aline Gratien*, ${ }^{\dagger}$, Manon Ropion ${ }^{\dagger}$, Edouard Pangui ${ }^{\dagger}$ and JeanFrançois Doussin ${ }^{\dagger}$.

${ }^{\dagger}$ Laboratoire Interuniversitaire des Systèmes Atmosphériques (LISA), UMR7583, CNRS, Université Paris-Est-Créteil (UPEC) et Université de Paris, Institut Pierre Simon Laplace (IPSL), Créteil, France

\section{Abstract}

Reaction rate constants for the reaction of $n$-dodecane with hydroxyl radicals were measured as a function of temperature between 283 and $303 \mathrm{~K}$, using the relative rate method in the CESAM chamber (French acronym for "Chamber for Atmospheric Multiphase Experimental Simulation"). The rate constants obtained at 283,293 and $303 \mathrm{~K}$ are $(1.27 \pm 0.31) \times 10^{-11}$, $(1.33 \pm 0.34) \times 10^{-11}, \quad(1.27 \pm 0.40) \times 10^{-11} \mathrm{~cm}^{3}$ molecule ${ }^{-1} \mathrm{~s}^{-1}, \quad$ respectively. Rate constants measured were in excellent agreement with the few available data in the literature over the studied temperature range $(283-340 \mathrm{~K})$. Rate constants estimated by the structure-activity relationship and transition state theory methods agreed with our experimental data within 14 $\%$. From these data combined with previous literature measurement, the following Arrhenius expression; $k_{D D C+O H}=(9.77 \pm 6.19) 10^{-11} \times \exp \left[\frac{-595 \pm 5580}{T}\right] \mathrm{cm}^{3}$ molecule $^{-1} \mathrm{~S}^{-1}, \quad$ was found valid over a temperature range $(283-340 \mathrm{~K})$ of the tropospheric interest. 


\section{Introduction}

Alkanes are ubiquitous volatile organic compounds (VOCs) in the atmosphere. They are mostly emitted by human activities, including combustion sources, vehicle exhaust, and evaporation and comprise $40-50 \%$ of the anthropogenic VOCs in urban areas ${ }^{1-2}$. In particular, long-chain alkanes $(\mathrm{C}>10)$, which represent a significant fraction of the unresolved complex mixture of fossil fuel ${ }^{3-4}$. For example n-dodecane (DDC) mixing ratio in polluted area can reach up to $16.47 \mu \mathrm{g} / \mathrm{m}^{3}$ 5-6. Further, long chain alkanes are expected to exhibit during daytime a lifetime of 5-20 hours with respect to $\mathrm{OH}$-initiated oxidation - their main removal process - making them good contributors to atmospheric reactivity at local to regional scale ${ }^{7}$. Long-chain alkanes $(\mathrm{C}>10)$, have also been recognized to be high secondary organic aerosol (SOA) precursors ${ }^{8-12}$. While SOA impacts human health ${ }^{13}$ and global climate ${ }^{14}$, chemical transport models have difficulties to predict ambient SOA concentration ${ }^{15-17}$. To reduce the gap between measurement and modeled SOA, efforts have been recently continued to study the SOA formation from the oxidation of long-chain alkanes ${ }^{8-12,18-25}$. To date, the most studied alkane was n-dodecane (DDC), not only because of its potential contribution to SOA formation but also because - to its linear structure - it represents also a target molecule of choice to investigate the relative importance of the various radical pathways during the oxidation scheme. Fragmentation, functionalization and oligomerization are indeed key processes that determine both the product distribution and the related SOA yield. However, these studies were mainly performed at room temperature (295-298 K), while temperature is an important environmental factor, which both affect vapor pressure of the products, branching ratios and initiation rate constants. To date, only the study of Lamkaddam, et al. ${ }^{12}$ has investigated the SOA formation over a range of temperature $(283-304.5 \mathrm{~K})$. The latter showed a small effect of temperature on the SOA yields, indicating a chemical composition dominated by nonvolatile species such that a change in temperature would not change the partitioning. Therefore, 
in order to fully assess the impact of this class of compounds on the environment and to model its chemistry, a better knowledge of its oxidation kinetics is needed to more precisely represent the temperature dependence of the rate constant of $\mathrm{n}$-dodecane with $\mathrm{OH}$ radicals and disentangle the kinetic effects from the phase partitioning effects on the SOA yield.

Only a few experimental studies have provided reaction rate constants of $\mathrm{n}$-dodecane $\left(\mathrm{k}_{\mathrm{DDC}+\mathrm{OH}}\right)$ with $\mathrm{OH}$ radical at various temperature using the relative rate technique ${ }^{26-28}$. First determinations at atmospheric pressure from the Zetzsch's group have been reported to be $\mathrm{k}_{\mathrm{DDC}+\mathrm{OH}}=(1.39 \pm 0.01) \times 10^{-11} \mathrm{~cm}^{3}$ molecule $\mathrm{e}^{-1} \mathrm{~s}^{-1}$ at $300 \mathrm{~K}$ and $\mathrm{k}_{\mathrm{DDC}+\mathrm{OH}}=(1.50 \pm 0.05) \times 10^{-11}$ $\mathrm{cm}^{3}$ molecule $\mathrm{s}^{-1}$ at $312 \mathrm{~K}$ with n-octane and $\mathrm{n}$-heptane as reference compound, respectively from Behnke, et al. ${ }^{26}$ and Nolting, et al. ${ }^{27}$.

By exploring these experimental studies, Atkinson (2003) provided a recommended value of $(1.32 \pm 0.26) \times 10^{-11} \mathrm{~cm}^{3}$ molecule $\mathrm{s}^{-1} \mathrm{~s}^{-1}$ at $298 \mathrm{~K}$. In addition, measurements made by the Zetzsch's group has been re-evaluated using recent rate data for the reference compound by Atkinson ${ }^{7}$. The resulting re-evaluation led to reaction rate of $\mathrm{k}_{\mathrm{DDC}+\mathrm{OH}}=(1.29 \pm 0.02) \times 10^{-11}$ $\mathrm{cm}^{3}$ molecule ${ }^{-1} \mathrm{~s}^{-1}$ at $300 \mathrm{~K}$ and $\mathrm{k}_{\mathrm{DDC}+\mathrm{OH}}=(1.40 \pm 0.05) \times 10^{-11} \mathrm{~cm}^{3}$ molecule $\mathrm{e}^{-1} \mathrm{~s}^{-1}$ at $312 \mathrm{~K}$, respectively for the studies of Behnke, et al. ${ }^{26}$ and Nolting, et al. ${ }^{27}$.

Later, Phan and $\mathrm{Li}^{28}$ performed a low-pressure flow tube reactor coupled with a quadrupole mass spectrometer at $240-340 \mathrm{~K}$ with n-nonane and n-decane as reference compounds. They determined a reaction rate constant of $(1.83 \pm 0.26) \times 10^{-11} \mathrm{~cm}^{3}$ molecule $\mathrm{e}^{-1} \mathrm{~s}^{-1}$ at $298 \mathrm{~K}$, which was only in fair agreement considering their uncertainties with previous studies. Interestingly, in this study, from 277 to $340 \mathrm{~K}$, rate constants have been found to correlate positively with the temperature, while from 240 to $260 \mathrm{~K}$ a negative correlation has been observed.

In conclusion, despite these experimental studies, the atmospheric oxidation rate of $n$-dodecane is still subject to uncertainties ranging from $20 \%$ to $40 \%$. Therefore, to improve our knowledge of the atmospheric reactivity of n-dodecane, we present in this paper an additional investigation 
of the rate constant as a function of temperature $(283-303 \mathrm{~K})$ with the objective to converge toward a better-established temperature dependence of the rate constant of the reaction between $\mathrm{OH}$ radical and n-dodecane. In this study, reported reaction rate constants were obtained with the relative rate method, using isoprene (ISP) as reference compound.

\section{Material and Methods}

2.1. CESAM chamber. Experiments were performed in the CESAM chamber which has been described in detail elsewhere ${ }^{29}$. Briefly, it is an evacuable chamber comprising a stainless steel cylindrical vessel of $4.2 \mathrm{~m}^{3}$, equipped with three high-pressure xenon arc lamps $(4 \mathrm{~kW}$, MH Diffusion ${ }^{\circledR}$, MacBeam ${ }^{\mathrm{TM}} 4000$ ) and $6.5 \mathrm{~mm}$ thick Pyrex filter to filter out radiation below $300 \mathrm{~nm}$. During this set of experiments, $\mathrm{NO}_{2}$ photolysis frequency $\left(\mathrm{J}_{\mathrm{NO}}\right)$ was experimentally verified to be equal to $(1.74 \pm 0.14) \times 10^{-3} \mathrm{~s}^{-1}$. The reactor contains a double wall which allows the circulation of a coolant liquid using a thermostat (LAUDA Integral $\mathrm{T} 10000 \mathrm{~W}$ ). Thanks to this set-up, temperature was controlled at 283, 293 and $303 \mathrm{~K}$ with a maximum variation of $1.5 \mathrm{~K}$ during the course of an experiment. At the bottom of the reactor a stainless steel fan allowed a fast mixing of the gaseous species introduced within $60 \mathrm{~s}^{29}$

2.2. Measurement. Temperature and relative humidity were measured using a Vaisala ${ }^{\circledR}$ probe (HMP234). Studied and reference compounds were monitored using an in situ Fourier transform infrared (FTIR) spectroscopy (Bruker ${ }^{\circledR}$ Tensor37 $7^{\mathrm{TM}}$ ) coupled to a multipath path cell for a path length of $192 \pm 4 \mathrm{~m}$. Infrared spectra were obtained at a resolution of $0.5 \mathrm{~cm}^{-1}$ and derived from the co-addition of approximately 200 scans collected over $5 \mathrm{~min}$. Concentrations of the interest species were determined by subtracting pure reference spectra from spectra of reaction mixtures using homemade software based on matrix algebra. To guarantee the performance of the automatic routine, selected spectra for each experiment were subtracted manually and results were compared. Integrated band intensities (IBI, base log 10) of the main infrared absorption bands of the mixture compounds are $(1.03 \pm 0.02) \times 10^{-17} \mathrm{~cm} . \mathrm{molecule}^{-1}$ and 
$(3.97 \pm 0.13) \times 10^{-17} \mathrm{~cm} \cdot \mathrm{molecul}^{-1}$ for isoprene $\left(830-950 \mathrm{~cm}^{-1}\right)$ and n-dodecane $(3020-2820$ $\mathrm{cm}^{-1}$ ), respectively. Ozone was measured by a commercial UV absorption monitor (Horiba ${ }^{\circledR}$, APOA-370). A commercial chemiluminescence NOx analyzer (Horiba®, APNA-370) was used to monitor $\mathrm{NO}$ and $\mathrm{NO}_{2}$.

2.3. Experimental procedure of the kinetic study (relative rate technique). All experiments were carried out at atmospheric pressure. The chamber was filled with clean dry air by mixing 800 mbar of nitrogen produced from the evaporation of a pressurized liquid nitrogen tank (Messer, purity $>99.995 \%, \mathrm{H}_{2} \mathrm{O}<5 \mathrm{ppmv}$ ) and 200 mbar of oxygen (Air Liquide, ALPHAGAZTM class 1 , purity $99.9 \%$ ). Temperature was set and kept constant throughout the experiments at $283 \pm 1 \mathrm{~K}, 293 \pm 1 \mathrm{~K}$ and $303 \pm 1.5 \mathrm{~K} . n$-Dodecane ( $\geq 99 \%$, Sigma Aldrich) is a semi-volatile specie that may be difficult to introduce quantitatively. In order to inject it into the chamber without being off the volatility equilibrium and generate unwanted phase exchange, DDC was introduced by evaporating a known mass quantity through a gently heated glass tube at $333 \mathrm{~K}$ via $\mathrm{N}_{2}$ stream into the chamber. To accurately quantify the $n$-dodecane introduction, the glass tube was weighed before and after the injection with the help of a balance (METTLER TOLEDO, XA205DU) providing a precision of $0.1 \mathrm{mg}$. Isoprene ( $\geq 99 \%$, Sigma Aldrich), the reference compound, was injected into the chamber by flushing a known amount of vapor via a calibrated glass bulb. OH radicals were produced by photolysis of nitrous acid (HONO) added to the chamber:

$$
\mathrm{HONO}+\mathrm{h} v \rightarrow \mathrm{OH}+\mathrm{NO}
$$

HONO was synthetized from the drop-wise addition of sulfuric acid $\left(10^{-2} \mathrm{M}\right)$ into a solution of $\mathrm{NaNO}_{2}(0.1 \mathrm{M})$ and was carried into the reactor with a flow of $\mathrm{N}_{2}$. In some experiments, $\mathrm{HONO}$ was produced from $\mathrm{NO}_{2}\left(99 \%\right.$, Air Liquide) wall reaction ${ }^{29-31}$, which was injected with a gastight syringe and a septum valve. $\mathrm{NO}_{2}$ injection was followed with an introduction of water through a bubbler and resulted in $5 \%$ relative humidity $(\mathrm{RH})$ in the chamber. The production 
mechanism of HONO during the heterogeneous hydrolysis of $\mathrm{NO}_{2}$ in the dark is given as follow:

$$
2 \mathrm{NO}_{2}+\mathrm{H}_{2} \mathrm{O} \stackrel{\text { wall }}{\longrightarrow} \mathrm{HONO}+\mathrm{HNO}_{3}
$$

Before turning on the lamps, initial concentrations were systematically measured for a minimum of 15 minutes in order to derive first order reactant loss rates. Initial conditions of the reference and target compounds at each temperature are given in Table 1. Indeed, as we are using a relative rate method to determine the reaction rate constants $\left(\mathrm{k}_{\mathrm{DDC}+\mathrm{OH}}\right)$ of $\mathrm{n}$-dodecane with $\mathrm{OH}$ radical, it was crucial that $\mathrm{OH}$ was the only oxidant responsible for the decay of the target and reference compounds. Rate constants for the reaction of $\mathrm{OH}$ can be reliably determined by monitoring the simultaneous decay of the studied and reference compound in presence of $\mathrm{OH}$ radicals:

$$
\begin{gathered}
\text { n-Dodecane }+\mathrm{OH} \rightarrow \text { products (1) } \\
\text { Isoprene }+\mathrm{OH} \rightarrow \text { products (2) }
\end{gathered}
$$

Consequently, a flow of $\mathrm{NO}$ diluted in $\mathrm{N}_{2}$ from a 8 ppm gas cylinder ( 8 ppm in $\mathrm{N}_{2}$, Air Liquide, Alphagaz 1) was adjusted between 0.5 LPM and 1 LPM to systematically minimize the $\mathrm{O}_{3}$ production $\left(\mathrm{NO}+\mathrm{O}_{3} \rightarrow \mathrm{NO}_{2}+\mathrm{O}_{2}\right.$ ). Results of the $\mathrm{O}_{3}$ titration allowed us to keep $\mathrm{O}_{3}$ mixing ratio below $20 \mathrm{ppb}$ so that ozonolysis remains always negligible. Maximum $\mathrm{O}_{3}$ concentrations during the experiments are given in Table 1.

As the CESAM chamber is rigid, instrumental sampling flows results in a decrease of the pressure, which need to be compensated by an addition of synthetic air to keep the pressure constant during the whole experiments. This procedure induces a continuous dilution loss of the reaction mixture, ranging from $5.9 \times 10^{-6}$ to $1.4 \times 10^{-5} \mathrm{~s}^{-1}$. n-Dodecane being semi-volatile has also been sensitive to deposition on the wall of the chamber, but only during the experiments carried out at $283 \mathrm{~K}$. The wall loss rate of $\mathrm{n}$-dodecane has been assessed during 1- 
$2 \mathrm{~h}$ in dark period. In consequence, the integrated equation of the chemical system yields to the following:

$$
\operatorname{Ln}\left(\frac{[\mathrm{DDC}]_{\mathrm{t}_{0}}}{[\mathrm{DDC}]_{\mathrm{t}}}\right)-\left(k_{w}+k_{d i l}\right) \times\left(\mathrm{t}-\mathrm{t}_{0}\right)=\frac{\mathrm{k}_{\mathrm{DDC}+\mathrm{OH}}}{\mathrm{k}_{\mathrm{ISP}+\mathrm{OH}}} \times\left[\operatorname{Ln}\left(\frac{[\mathrm{ISP}]_{\mathrm{t}_{0}}}{[\mathrm{ISP}]_{\mathrm{t}}}\right)-k_{d i l} \times\left(\mathrm{t}-\mathrm{t}_{0}\right)\right](3)
$$

where $[\mathrm{DDC}]_{\mathrm{t}_{0}}$ and $[\mathrm{ISP}]_{\mathrm{t}_{0}}$ are the initial concentration of $\mathrm{n}$-dodecane and isoprene (at time $\left.\mathrm{t}_{0}\right)$; $[\mathrm{DDC}]_{t}$ and $[\mathrm{ISP}]_{t}$ are the corresponding concentration (at time $\mathrm{t}$ ); $\mathrm{k}_{\mathrm{w}}$ and $\mathrm{k}_{\mathrm{dil}}$ are rate constants to account for vapor wall- and dilution- losses respectively. Therefore, plotting the first term of Eq. (3) as a function of the second term should yield a straight line with zero intercept and

slope $\frac{\mathrm{k}_{\mathrm{DDC}+\mathrm{OH}}}{\mathrm{k}_{\mathrm{ISP}+\mathrm{OH}}}$ (see figure 1). The Arrhenius expression of isoprene with $\mathrm{OH}$ radical used was equal to $(2.7 \pm 0.1) \times 10^{-11} \exp (390 \pm 100 / \mathrm{T})\left(\right.$ in $^{3} \mathrm{~cm}^{3}$ molecule $\left.\mathrm{s}^{-1}\right)$ in the temperature range $240-340 \mathrm{~K}^{32}$. Reaction rate constants of isoprene with $\mathrm{OH}$ radical $\mathrm{k}_{\mathrm{ISP}+\mathrm{OH}}$ at different temperature are given in Table 2. The Arrhenius expression from Atkinson, et al. ${ }^{32}$ has been chosen as it represents the recommendation of IUPAC Sub-committee. Note the reported kinetic rate constant from IUPAC was in excellent agreement with the following available literature for isoprene reaction with $\mathrm{OH}^{33-34}$

\section{Results and discussion}

Obviously, the photooxidation of $\mathrm{n}$-dodecane and isoprene under high- $\mathrm{NO}_{\mathrm{x}}$ condition might produce $\mathrm{O}_{3}$ molecules, which could react further with isoprene, the reference compound. This reaction might lead to error in determination of the reaction rate constant of $n$-dodecane with $\mathrm{OH}$ radical. In consequence, a continuous injection of $\mathrm{NO}$ was manually adjusted to minimize the $\mathrm{O}_{3}$ production. In order to assess and make sure that $\mathrm{O}_{3}$ did not bias our measurements, lifetime with regards to $\mathrm{OH}$ and $\mathrm{O}_{3}$ has been evaluated with the following calculation:

$$
\frac{k_{O_{3}+I S P}\left[O_{3}\right]}{k_{O H+I S P}[O H]}
$$

with $k_{O_{3}+I S P}=(1.13 \pm 0.09) \times 10^{-17} \mathrm{~cm}^{3}$ molecule $\mathrm{s}^{-1}$ at $293 \mathrm{~K}^{32}$ and $k_{O H+I S P}=(1.02 \pm 0.15)$ $\times 10^{-10} \mathrm{~cm}^{3}$ molecule ${ }^{-1} \mathrm{~s}^{-1}$ at $293 \mathrm{~K}^{32}$. In the worst-case scenario, when $\mathrm{O}_{3}$ reached it maximum 
mixing ratio, i.e. $20 \mathrm{ppb}, \mathrm{OH}$ reaction with isoprene was still being the highest sink in comparison to $\mathrm{O}_{3}$, since the estimated lifetime ratio was 40. In other words, this procedure has guaranteed that $\mathrm{OH}-\mathrm{oxidation}$ of isoprene was always and by far the main oxidative process (99.86\% OH-oxidation vs $0.14 \%$ ozonolysis).

Control experiments under irradiation have shown negligible loss of isoprene $\left(<10^{-6} \mathrm{~s}^{-1}\right)$ at all temperature investigated. For n-dodecane, these losses were also below $<10^{-6} \mathrm{~s}^{-1}$ at $303 \mathrm{~K}$ and $293 \mathrm{~K}$ while at $283 \mathrm{~K}$ we were able to measure a loss of $(1.57 \pm 0.09) \times 10^{-6} \mathrm{~s}^{-1}$ (or $\tau=177 \mathrm{~h}$, $\tau=1 / \mathrm{k}_{\text {loss}}$, with $\mathrm{k}_{\text {loss }}$ the rate constant of loss processes) that were due to wall adsorption.

From the $\mathrm{n}$-dodecane mixing ratio decay and $\mathrm{n}$-dodecane $+\mathrm{OH}$ rate constant $\left(\mathrm{k}_{\mathrm{DDC}+\mathrm{OH}}\right)$, a mean concentration of $\mathrm{OH}$ radicals of $2 \times 10^{6}$ molecules $\mathrm{cm}^{-3}$ has been evaluated. Considering this value, typical lifetimes $(\tau=1 / \mathrm{kX}+\mathrm{OH}[\mathrm{OH}]$, with $\mathrm{X}=\mathrm{DDC}$ or ISP $)$ in our experiments of $\mathrm{n}$ dodecane and isoprene are 10.5 and $1.3 \mathrm{~h}$, respectively. In consequence, within the duration of the experiments, roughly an hour, wall and photolysis losses were clearly negligible in comparison to $\mathrm{OH}$-oxidation in this study, except at $283 \mathrm{~K}$ where a slight correction from the n-dodecane wall deposition was accounted.

Plots of the relative rate measurements at 283,293 and $303 \mathrm{~K}$ for the reaction of $\mathrm{n}$-dodecane with $\mathrm{OH}$ radical using isoprene as reference compound are shown in Figure 1. As seen in the later plot, two to three isothermal experiments were carried out and are in very good agreement. As expected from Equation 3, for all decay data points, a linear correlation is obtained with intercept close to zero within the uncertainties. The rate constant ratios $\left(\mathrm{k}_{\mathrm{DDC}+\mathrm{OH}} / \mathrm{k}_{\mathrm{ISP}+\mathrm{OH}}\right)$ was obtained by applying a linear regression, taking into account both the uncertainties on $\mathrm{x}$ - and y-axis as recommended by Brauers and Finlayson-Pitts ${ }^{35}$ (cf. Table 2 and Figure 1). These latter were evaluated from injection calibration of both studied and reference compounds. Uncertainties on $\mathrm{k}_{\mathrm{DDC}+\mathrm{OH}} / \mathrm{k}_{\mathrm{ISP}+\mathrm{OH}}$ correspond to $2 \sigma$ (with $\sigma$ the standard deviation of the linear regression). $\mathrm{k}_{\mathrm{ISP}+\mathrm{OH}}$ (from Atkinson, et al. ${ }^{32}$ ) and $\mathrm{k}_{\mathrm{DDC}+\mathrm{OH}} / \mathrm{k}_{\mathrm{ISP}+\mathrm{OH}}, \mathrm{k}_{\mathrm{DDC}+\mathrm{OH}}$ are given in Table 
2 at different temperature. Error on $\mathrm{k}_{\mathrm{DDC}+\mathrm{OH}}$ (i.e. given in Table 2) were determined from the quadratic sum of the error of $\mathrm{k}_{\mathrm{ISP}+\mathrm{OH}}$ and $\mathrm{k}_{\mathrm{DDC}+\mathrm{OH}} / \mathrm{k}_{\mathrm{ISP}+\mathrm{OH}}$.

Average of the rate constants at 283,293 and $303 \mathrm{~K}$ yielded to $(1.27 \pm 0.31) \times 10^{-11}$, $(1.33 \pm 0.34) \times 10^{-11},(1.27 \pm 0.40) \times 10^{-11} \mathrm{~cm}^{3}$ molecule $\mathrm{e}^{-1} \mathrm{~s}^{-1}$, respectively. Errors on the average rate constants correspond to the mean standard deviation. A plot of the average rate constants obtained from our work is given in Figure 2 with the available literature data at different temperatures. As we can see from this figure, reported rate constants at $300 \mathrm{~K}$ by Behnke, et al. ${ }^{26}$ (as reevaluated by Atkinson ${ }^{7}$ ) and at $312 \mathrm{~K}$ by Nolting, et al. ${ }^{27}$ (as reevaluated by Atkinson ${ }^{7}$ ) showed a good agreement within 2 and $9 \%$, respectively, with our determination at $303 \mathrm{~K}$ considering the error domain. Please note reaction rates by Phan and $\mathrm{Li}^{28}$ has been re-evaluated with the recommended $298 \mathrm{~K}$ rate constant for the reference compound, leading to a reaction rate of $(1.57 \pm 0.24) \times 10^{-11} \mathrm{~cm}^{3}$ molecule ${ }^{-1} \mathrm{~s}^{-1}$. As a consequence, comparison of our work at $303 \mathrm{~K}$ with the re-evaluated $298 \mathrm{~K}$ value from Phan and $\mathrm{Li}^{28}$ agreed within $19 \%$ considering the uncertainties. In the same way, recommended Arrhenius parameters for the reference compound provided by Atkinson (2003) has been used to estimate rate constants for the temperature ranges $(298-1110 \mathrm{~K})$ over which these recommendations are applicable. As shown in Figure 2, the effect of this re-evaluation decreased slightly the reaction rate constant by $6 \%$ at $320 \mathrm{~K}$ and $2 \%$ at $340 \mathrm{~K}$. The theoretical study from Sivaramakrishnan and Michael ${ }^{36}$ and the recommendation from Atkinson (2003) are in excellent agreement with our work, which is coherent since they were determined from the studies of Nolting, et al. ${ }^{27}$ and Behnke, et al. ${ }^{26}$.

The rate constants were also plotted with the Arrhenius expression $(283-340 \mathrm{~K})$ $k_{D D C+O H}=(9.77 \pm 6.19) 10^{-11} \times \exp \left[\frac{-595 \pm 5580}{T}\right] \mathrm{cm}^{3}$ molecule ${ }^{-1} \mathrm{~S}^{-1}, \quad$ which $\quad$ was determined by linear least-square analysis of $\ln (\mathrm{k})$ against $1 / \mathrm{T}$. Note that the Arrhenius fit was weighed by error bars and was determined from our work combined with rate constants 
reported by Behnke, et al. ${ }^{26}$, Nolting, et al. ${ }^{27}$ and Phan and $\mathrm{Li}^{28}$. The study of Phan and $\mathrm{Li}{ }^{28}$ that has led to somewhat outlying results is not without any potential issue. First, the use of a quadrupole mass spectrometer with electronic impact ionization source and unit mass resolution coupled with a flow tube might have induced uncertainties in the determination of reaction rate constants since the fragmentation pattern of secondary oxidation products from long chain alkane would recurrently present the same ion of the parent precursor due to the simple loss of stable neutral species (e.g. $\mathrm{H}_{2}, \mathrm{OH}, \mathrm{H}_{2} \mathrm{O}, \mathrm{H}_{2} \mathrm{O}_{2},\left(\mathrm{CH}_{2}\right)$ n, etc. $)^{37}$. Second, oxidation products from both DDC and reference compounds used in their study, i.e. n-nonane and n-decane, might also have contributed to the DDC peaks in the mass spectra. Therefore, the effect of secondary reactions within the flow tube reactor would potentially bias the determination of the reaction rates. In addition, despite the low pressure system ( $\mathrm{P}=1-5$ Torr), the saturation vapor pressure of n-dodecane - i.e $7.6 \times 10^{-4}$ Torr at $240 \mathrm{~K}$ and 5.32 Torr at 340 K estimated with the prediction method by Nannoolal, et al. ${ }^{38}$ - decreases by several order of magnitude with the temperature. Consequently, the negative correlation from 240 to $277 \mathrm{~K}$ might be explained by the additional deposition of the n-dodecane vapor to the flow tube wall, which is not considered in their integrated kinetic equations. In other words, the reported negative correlation with temperature from 240 to $260 \mathrm{~K}$ might be explained by the increase of the vapor wall loss rate of n-dodecane. Since we can not rule out these measurement biases from Phan and $\mathrm{Li}^{28}$ 's, non-re-evaluated rate constants from 240 to $277 \mathrm{~K}$ were excluded from the Arrhenius fit. Uncertainties of the Arrhenius parameters (A, the pre-exponential factor, and $\mathrm{Ea} / \mathrm{R}$, the ratio of activation energy over ideal gas constant) are $\pm 2 \sigma$ of the fit.

As shown in Figure 2 from 283 to $340 \mathrm{~K}$, the reactivity between the n-dodecane and $\mathrm{OH}$ radicals shows a relatively low positive temperature dependence. This observation is in good agreement with the well-known hydrogen-atom abstraction mechanism. ${ }^{39}$ In addition, this low temperature dependence observed, in the typical tropospheric temperature range, is consistent 
with low activation energy reactions such as a long chain alkane with $\mathrm{OH}$ radicals ( ${ }^{7}$ and references therein).. It would be interesting to investigate further the temperature effect of the reaction rate constant with particular care of the vapor wall deposition of the target compound to validate/invalidate observation from Phan and $\mathrm{Li}^{28}$.

The obtained rate constants for the reaction of $\mathrm{n}$-dodecane with $\mathrm{OH}$ radicals can be estimated with prediction methods. These later are based upon the group-additivity transition-state theory (TST) described in Sivaramakrishnan and Michael ${ }^{36}$ and the structure activity relationship (SAR) method detailed by Kwok and Atkinson ${ }^{40}$. As seen in Figure 2, application of these prediction methods shows a nice agreement with our data and represents very well the low temperature dependence on the reactivity.

\section{Conclusion}

In this work, reaction rate constants of n-dodecane with $\mathrm{OH}$ radicals as a function of the temperature were determined between 283 and $303 \mathrm{~K}$, using the relative rate method with the CESAM chamber. Rate constants measured are in excellent agreement with the literature and those estimated by the SAR and TST methods agreed reasonably, i.e. within 14\%. Arrhenius expression were developed over a fair range of temperature $(283 \mathrm{~K}-340 \mathrm{~K})$, representative of the troposphere. These kinetic data can be used to assess the atmospheric chemical lifetimes $\left(\tau=1 / \mathrm{k}_{\mathrm{DDC}+\mathrm{OH}}[\mathrm{OH}]\right)$ of the $\mathrm{n}$-dodecane with the $\mathrm{OH}$ oxidants. Using this relation and a typical tropospheric $\mathrm{OH}$ concentration of $2 \times 10^{6}$ molecule $\mathrm{cm}^{-3}{ }^{41}$, the atmospheric lifetime was found to be $10.7 \mathrm{~h}$ at room temperature $(298 \mathrm{~K})$. Therefore, it appears that n-dodecane is likely to be removed rapidly and degraded relatively near to its emission sources. It may hence participate to the ozone and SOA burden at local/regional scale downwind urbanized/industrial area.

\section{Corresponding Author}

*Email: aline.gratien@lisa.u-pec.fr 


\section{Present address:}

‡ Paul Scherrer Institute, Laboratory of Atmospheric Chemistry, CH-5232 Villigen-PSI, Switzerland

\section{Acknowledgments}

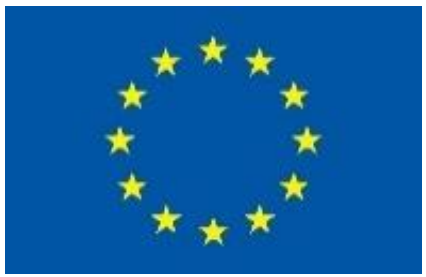

This work was supported through the project "Atmospheric oxidation of $n$-dodecane: fundamental studies and parameterization of SOA formation (Dodec-AOS)" within the PN-LEFE CHAT program (French National Program of Atmospheric Chemistry). In addition, CNRS-INSU is gratefully acknowledged for supporting the CESAM chamber as a national facility as well as the AERIS data center for distributing and curing the data produced by the CESAM chamber. This work was also supported by the European Community within the $7^{\text {th }}$ Framework Program, section "Support for Research Infrastructure - Integrated Infrastructure Initiative": EUROCHAMP-2, by the European Union's Horizon 2020 research and innovation program through the EUROCHAMP-2020 Infrastructure Activity under grant agreement ${ }^{\circ} 730997$.

\section{References}

1. Calvert, J. G. A., R.; Becker, K. H.; Kamens, R. M.; Seinfeld, J. H.; Wallington, T. J.; Yarwood, G., The Mechanisms of Atmospheric Oxidation of Aromatic Hydrocarbons. OUP USA 2002.

2. Schauer, J. J.; Kleeman, M. J.; Cass, G. R.; Simoneit, B. R. T., Measurement of Emissions from Air Pollution Sources. 4. C1-C27 Organic Compounds from Cooking with Seed Oils. Environ. Sci. Technol. 2002, 36 (4), 567-575.

3. Gentner, D. R.; Isaacman, G.; Worton, D. R.; Chan, A. W. H.; Dallmann, T. R.; Davis, L.; Liu, S.; Day, D. A.; Russell, L. M.; Wilson, K. R.; et al., Elucidating secondary organic aerosol from diesel and gasoline vehicles through detailed characterization of organic carbon emissions. Proc. Natl. Acad. Sci. U.S.A 2012, 109 (45), 18318-18323.

4. $\quad$ Chan, A. W. H.; Isaacman, G.; Wilson, K. R.; Worton, D. R.; Ruehl, C. R.; Nah, T.; Gentner, D. R.; Dallmann, T. R.; Kirchstetter, T. W.; Harley, R. A.; et al., Detailed chemical characterization of unresolved complex mixtures in atmospheric organics: Insights into emission sources, atmospheric 
processing, and secondary organic aerosol formation. J. Geophys. Res.: Atmospheres 2013, 118 (12), 6783-6796.

5. $\quad$ Fraser, M. P.; Cass, G. R.; Simoneit, B. R., Gas-phase and particle-phase organic compounds emitted from motor vehicle traffic in a Los Angeles roadway tunnel. Environ. Sci. Technol. 1998, 32 (14), 2051-2060.

6. Herbarth, O.; Rehwagen, M.; Herbarth, O.; Ronco, A. E., The influence of localized emittants on the concentration of volatile organic compounds in the ambient air measured close to ground level. Environ. Toxicol. Water Qual. 1997, 12 (1), 31-37.

7. Atkinson, R., Kinetics of the gas-phase reactions of $\mathrm{OH}$ radicals with alkanes and cycloalkanes. Atmos. Chem. Phys. 2003, 3 (6), 2233-2307.

8. Lim, Y. B.; Ziemann, P. J., Products and Mechanism of Secondary Organic Aerosol Formation from Reactions of n-Alkanes with OH Radicals in the Presence of NOx. Environ. Sci. Technol. 2005, 39 (23), 9229-9236.

9. Lim, Y. B.; Ziemann, P. J., Effects of Molecular Structure on Aerosol Yields from OH RadicalInitiated Reactions of Linear, Branched, and Cyclic Alkanes in the Presence of NOx. Environ. Sci. Technol 2009b, 43 (7), 2328-2334.

10. Presto, A. A.; Miracolo, M. A.; Donahue, N. M.; Robinson, A. L., Secondary Organic Aerosol Formation from High-NOx Photo-Oxidation of Low Volatility Precursors: n-Alkanes. Environ. Sci. Technol. 2010, 44 (6), 2029-2034.

11. Tkacik, D. S.; Presto, A. A.; Donahue, N. M.; Robinson, A. L., Secondary Organic Aerosol Formation from Intermediate-Volatility Organic Compounds: Cyclic, Linear, and Branched Alkanes. Environ. Sci. Technol. 2012, 46 (16), 8773-8781.

12. Lamkaddam, H.; Gratien, A.; Pangui, E.; Cazaunau, M.; Picquet-Varrault, B.; Doussin, J.-F., HighNOx Photooxidation of n-Dodecane: Temperature Dependence of SOA Formation. Environ. Sci. Technol. 2017, 51 (1), 192-201.

13. Pope, C. A.; Burnett, R. T.; Turner, M. C.; Cohen, A.; Krewski, D.; Jerrett, M.; Gapstur, S. M.; Thun, M. J., Lung Cancer and Cardiovascular Disease Mortality Associated with Ambient Air Pollution and Cigarette Smoke: Shape of the Exposure-Response Relationships. Environ. Health Perspect. 2011, 119 (11), 1616-1621.

14. IPCC, Climate Change 2013: The Physical Science Basis. 2013.

15. Heald, C. L.; Coe, H.; Jimenez, J. L.; Weber, R. J.; Bahreini, R.; Middlebrook, A. M.; Russell, L. M.; Jolleys, M.; Fu, T. M.; Allan, J. D.; et al., Exploring the vertical profile of atmospheric organic aerosol: comparing 17 aircraft field campaigns with a global model. Atmos. Chem. Phys. 2011, 11 (24), 12673-12696.

16. Ensberg, J. J.; Hayes, P. L.; Jimenez, J. L.; Gilman, J. B.; Kuster, W. C.; de Gouw, J. A.; Holloway, J. S.; Gordon, T. D.; Jathar, S.; Robinson, A. L.; et al., Emission factor ratios, SOA mass yields, and the impact of vehicular emissions on SOA formation. Atmos. Chem. Phys. 2014, 14 (5), 2383-2397.

17. Hodzic, A.; Kasibhatla, P. S.; Jo, D. S.; Cappa, C. D.; Jimenez, J. L.; Madronich, S.; Park, R. J., Rethinking the global secondary organic aerosol (SOA) budget: stronger production, faster removal, shorter lifetime. Atmos. Chem. Phys. 2016, 16 (12), 7917-7941.

18. Lim, Y. B.; Ziemann, P. J., Chemistry of Secondary Organic Aerosol Formation from OH RadicalInitiated Reactions of Linear, Branched, and Cyclic Alkanes in the Presence of NO x. Aerosol Sci. Technol. 2009a, 43 (6), 604-619.

19. Yee, L. D.; Craven, J. S.; Loza, C. L.; Schilling, K. A.; Ng, N. L.; Canagaratna, M. R.; Ziemann, P. J.; Flagan, R. C.; Seinfeld, J. H., Secondary Organic Aerosol Formation from Low-NOx Photooxidation of Dodecane: Evolution of Multigeneration Gas-Phase Chemistry and Aerosol Composition. J. Phys. Chem. A 2012, 116 (24), 6211-6230.

20. Yee, L. D.; Craven, J. S.; Loza, C. L.; Schilling, K. A.; Ng, N. L.; Canagaratna, M. R.; Ziemann, P. J.; Flagan, R. C.; Seinfeld, J. H., Effect of chemical structure on secondary organic aerosol formation from C12 alkanes. Atmos. Chem. Phys. 2013, 13 (21), 11121-11140. 
21. Loza, C. L.; Craven, J. S.; Yee, L. D.; Coggon, M. M.; Schwantes, R. H.; Shiraiwa, M.; Zhang, X.; Schilling, K. A.; Ng, N. L.; Canagaratna, et al., Secondary organic aerosol yields of 12-carbon alkanes. Atmos. Chem. Phys. 2014, 14 (3), 1423-1439.

22. Yeh, G. K.; Ziemann, P. J., Alkyl Nitrate Formation from the Reactions of C8-C14 n-Alkanes with $\mathrm{OH}$ Radicals in the Presence of NOx: Measured Yields with Essential Corrections for Gas-Wall Partitioning. J. Phys. Chem. A 2014a, 118 (37), 8147-8157.

23. Yeh, G. K.; Ziemann, P. J., Identification and Yields of 1,4-Hydroxynitrates Formed from the Reactions of C8-C16 n-Alkanes with OH Radicals in the Presence of NOx. J. Phys. Chem. A 2014b, 118 (38), 8797-8806.

24. Takekawa, H.; Minoura, H.; Yamazaki, S., Temperature dependence of secondary organic aerosol formation by photo-oxidation of hydrocarbons. Atmos. Environ. 2003, 37 (24), 3413-3424.

25. Zhang, X.; Schwantes, R. H.; Coggon, M. M.; Loza, C. L.; Schilling, K. A.; Flagan, R. C.; Seinfeld, J. H., Role of ozone in SOA formation from alkane photooxidation. Atmos. Chem. Phys. 2014, 14 (3), 1733-1753.

26. Behnke, W.; Holländer, W.; Koch, W.; Nolting, F.; Zetzsch, C., A smog chamber for studies of the photochemical degradation of chemicals in the presence of aerosols. Atmos. Environ. (1967) 1988, 22 (6), 1113-1120.

27. Nolting, F.; Behnke, W.; Zetzsch, C., A smog chamber for studies of the reactions of terpenes and alkanes with ozone and OH. J. Atmos. Chem. 1988, 6 (1), 47-59.

28. Phan, M.; Li, Z., Kinetics Study of the Reactions of OH with n-Undecane and n-Dodecane Using the RR/DF/MS Technique. J. Phys. Chem. A 2017, 121 (19), 3647-3654.

29. Wang, J.; Doussin, J. F.; Perrier, S.; Perraudin, E.; Katrib, Y.; Pangui, E.; Picquet-Varrault, B., Design of a new multi-phase experimental simulation chamber for atmospheric photosmog, aerosol and cloud chemistry research. Atmos. Meas. Tech. 2011, 4 (11), 2465-2494.

30. Pitts, J. N.; Sanhueza, E.; Atkinson, R.; Carter, W. P. L.; Winer, A. M.; Harris, G. W.; Plum, C. N., An investigation of the dark formation of nitrous acid in environmental chambers. Int. J. Chem. Kinet. 1984, 16 (7), 919-939.

31. Ramazan, K. A.; Syomin, D.; Finlayson-Pitts, B. J., The photochemical production of HONO during the heterogeneous hydrolysis of NO2. Phys. Chem. Chem. Phys. 2004, 6 (14), 3836-3843.

32. Atkinson, R.; Baulch, D. L.; Cox, R. A.; Crowley, J. N.; Hampson, R. F.; Hynes, R. G.; Jenkin, M. E.; Rossi, M. J.; Troe, J.; Subcommittee, I., Evaluated kinetic and photochemical data for atmospheric chemistry: Volume II - gas phase reactions of organic species. Atmos. Chem. Phys. 2006, 6 (11), 36254055.

33. Vimal, D.; Pacheco, A. B.; Iyengar, S. S.; Stevens, P. S., Experimental and Ab Initio Dynamical Investigations of the Kinetics and Intramolecular Energy Transfer Mechanisms for the $\mathrm{OH}+1,3-$ Butadiene Reaction between 263 and $423 \mathrm{~K}$ at Low Pressure. J. Phys. Chem. A 2008, 112 (31), 72277237.

34. Singh, S.; Li, Z., Kinetics Investigation of OH Reaction with Isoprene at 240-340 K and 1-3 Torr Using the Relative Rate/Discharge Flow/Mass Spectrometry Technique. J. Phys. Chem. A 2007, 111 (46), 11843-11851.

35. Brauers, T.; Finlayson-Pitts, B. J., Analysis of relative rate measurements. Int. J. Chem. Kinet. 1997, 29 (9), 665-672.

36. Sivaramakrishnan, R.; Michael, J. V., Rate Constants for $\mathrm{OH}$ with Selected Large Alkanes: Shock-Tube Measurements and an Improved Group Scheme. J. Phys. Chem. A 2009, 113 (17), 50475060 .

37. McLafferty, F. W.; Tureček, F.; Turecek, F., Interpretation of mass spectra. University science books: 1993.

38. Nannoolal, Y.; Rarey, J.; Ramjugernath, D., Estimation of pure component properties: Part 3. Estimation of the vapor pressure of non-electrolyte organic compounds via group contributions and group interactions. Fluid Ph. Equilibria 2008, 269 (1-2), 117-133.

39. Calvert, J. G., Mechanisms of atmospheric oxidation of the alkanes. OUP USA: 2008. 
40. Kwok, E. S.; Atkinson, R., Estimation of hydroxyl radical reaction rate constants for gas-phase organic compounds using a structure-reactivity relationship: an update. Atmos. Environ. 1995, 29 (14), 1685-1695.

41. Finlayson-Pitts, B. J.; Pitts, J. N., Chemistry of the Upper and Lower Atmosphere: Theory, Experiments, and Applications. 2000. 


\section{Tables}

Table 1. Summary of the kinetic experiments.

\begin{tabular}{|c|c|c|c|c|c|c|c|}
\hline $\operatorname{Exp}$ & $\mathbf{T}(\mathrm{K})$ & $\begin{array}{l}\text { OH } \\
\text { source }\end{array}$ & $\begin{array}{l}{[\mathrm{DDC}]_{\mathrm{t} 0}} \\
(\mathrm{ppb})\end{array}$ & $\begin{array}{l}{[\mathrm{ISP}]_{\text {to }}} \\
(\mathrm{ppb})\end{array}$ & $\begin{array}{l}{\left[\mathrm{NO}_{2}\right]_{\mathbf{t} 0}} \\
(\mathbf{p p b})\end{array}$ & $\begin{array}{l}{\left[\mathrm{H}_{2} \mathrm{O}\right]} \\
\left(\text { molecule.cm }{ }^{-3}\right)\end{array}$ & $\begin{array}{l}{\left[\mathrm{O}_{3}\right]_{\max }} \\
\text { (ppb) }\end{array}$ \\
\hline E1.283 & $283 \pm 1$ & $\mathrm{NO}_{2}$ & $471 \pm 16$ & $93 \pm 3$ & 66 & $2.10 \times 10^{16}$ & 12 \\
\hline E2.283 & $283 \pm 1$ & $\mathrm{NO}_{2}$ & $592 \pm 21$ & $76 \pm 3$ & 18 & $2.00 \times 10^{15}$ & 15 \\
\hline E1.293 & $293 \pm 1$ & $\mathrm{NO}_{2}$ & $408 \pm 14$ & $76 \pm 3$ & 24 & $3.21 \times 10^{16}$ & 12 \\
\hline E2.293 & $293 \pm 1$ & HONO & $600 \pm 21$ & $86 \pm 3$ & 41 & $3.93 \times 10^{16}$ & 4 \\
\hline E1.303 & $303 \pm 1.5$ & HONO & $559 \pm 20$ & $63 \pm 2$ & 67 & $3.51 \times 10^{15}$ & 20 \\
\hline E2.303 & $303 \pm 1.5$ & HONO & $520 \pm 18$ & $57 \pm 2$ & 69 & $4.68 \times 10^{15}$ & 18 \\
\hline E3.303 & $303 \pm 1.5$ & $\mathrm{NO}_{2}$ & $641 \pm 22$ & $93 \pm 3$ & 34 & $6.58 \times 10^{16}$ & 20 \\
\hline
\end{tabular}


Table 2. Measured rate constants for the $\mathrm{OH}$-oxidation of n-dodecane (DDC) with isoprene (ISP) as reference compound ${ }^{32}$ in the temperature range $283-303 \mathrm{~K}$.

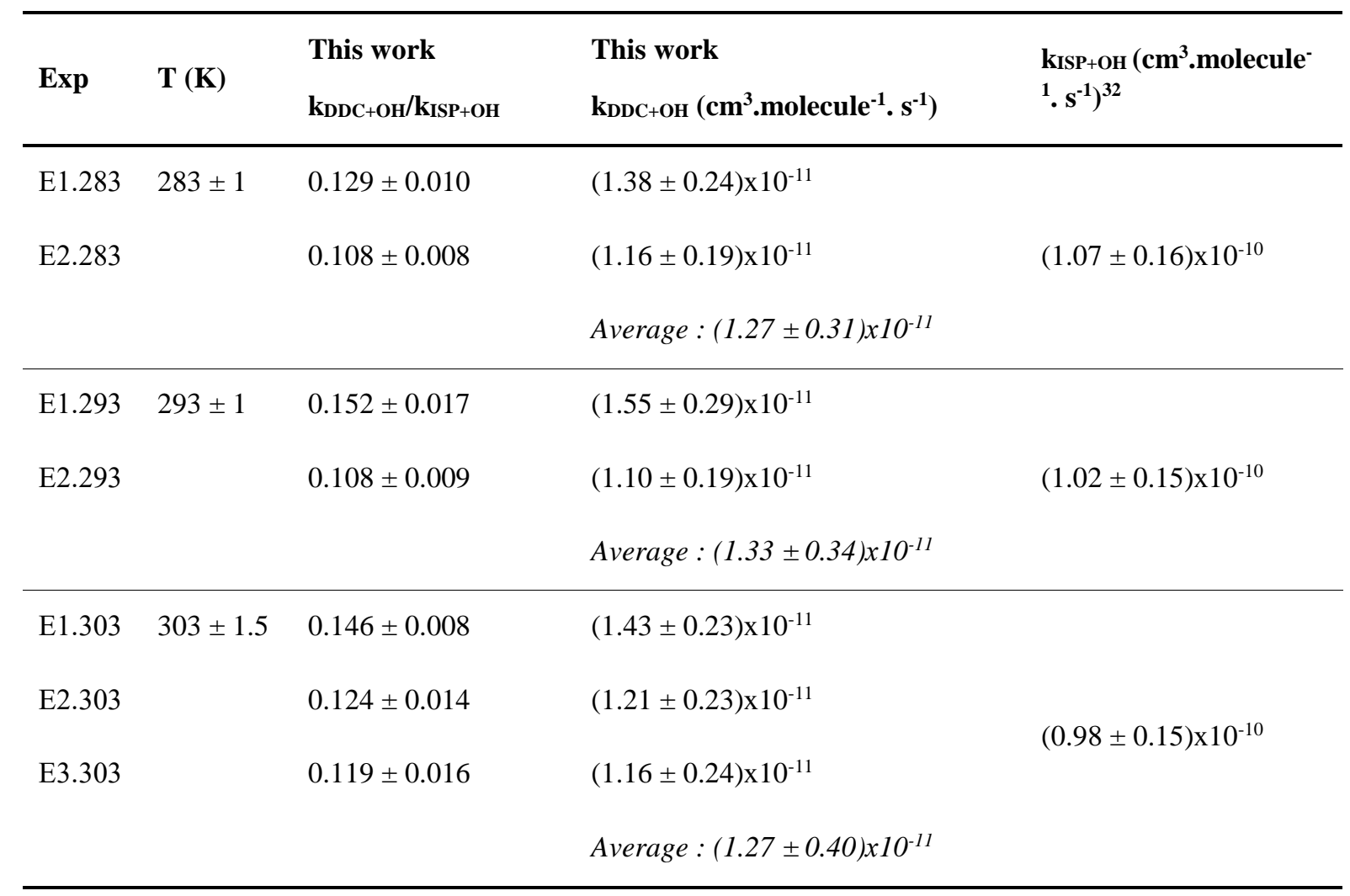




\section{Figures}
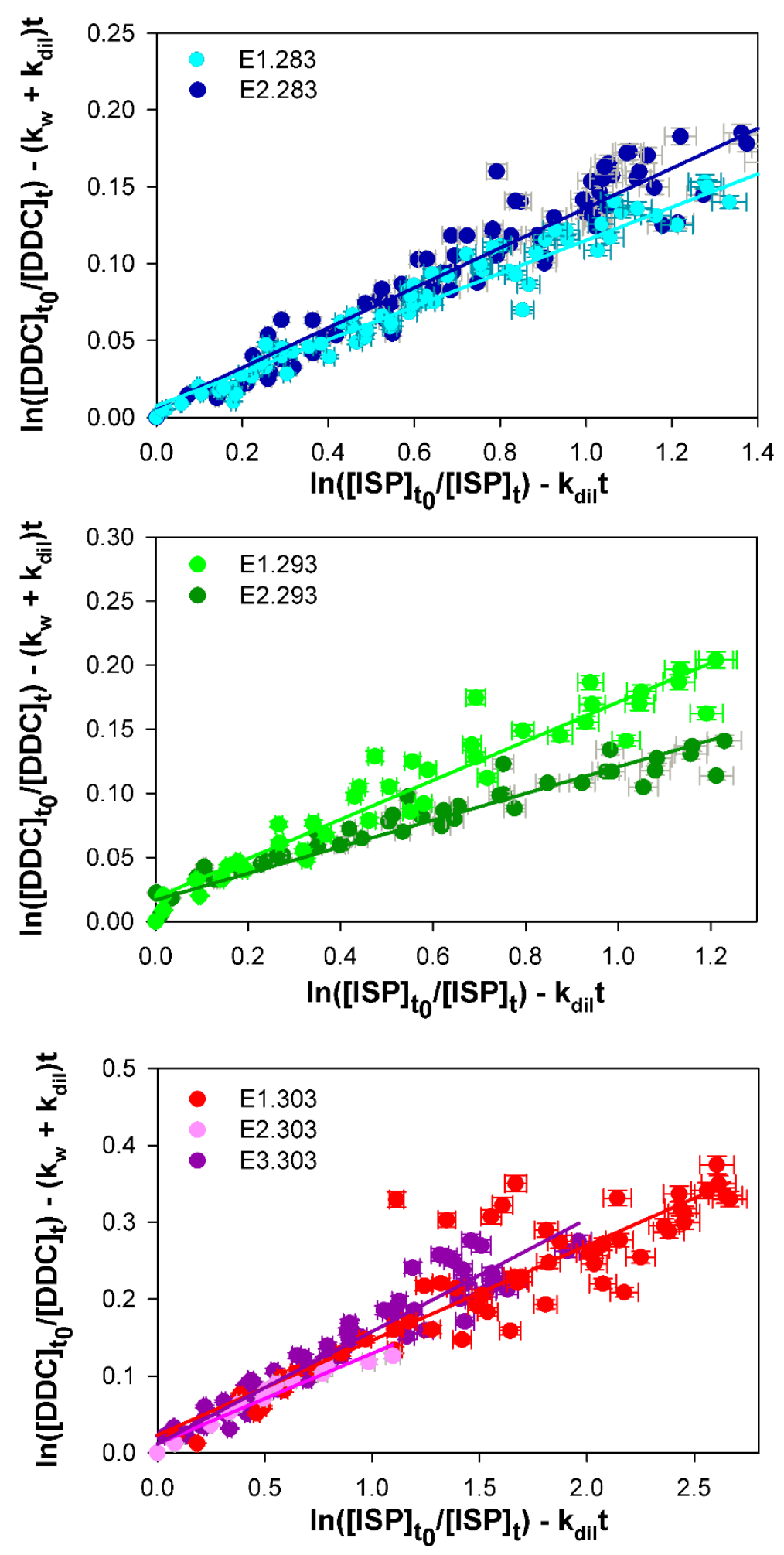

Figure 1. Relative kinetic plots for OH-oxidation of n-dodecane with isoprene as a reference compound, at $283 \mathrm{~K}$ (top panel), $293 \mathrm{~K}$ (middle panel) and $303 \mathrm{~K}$ (bottom panel). 


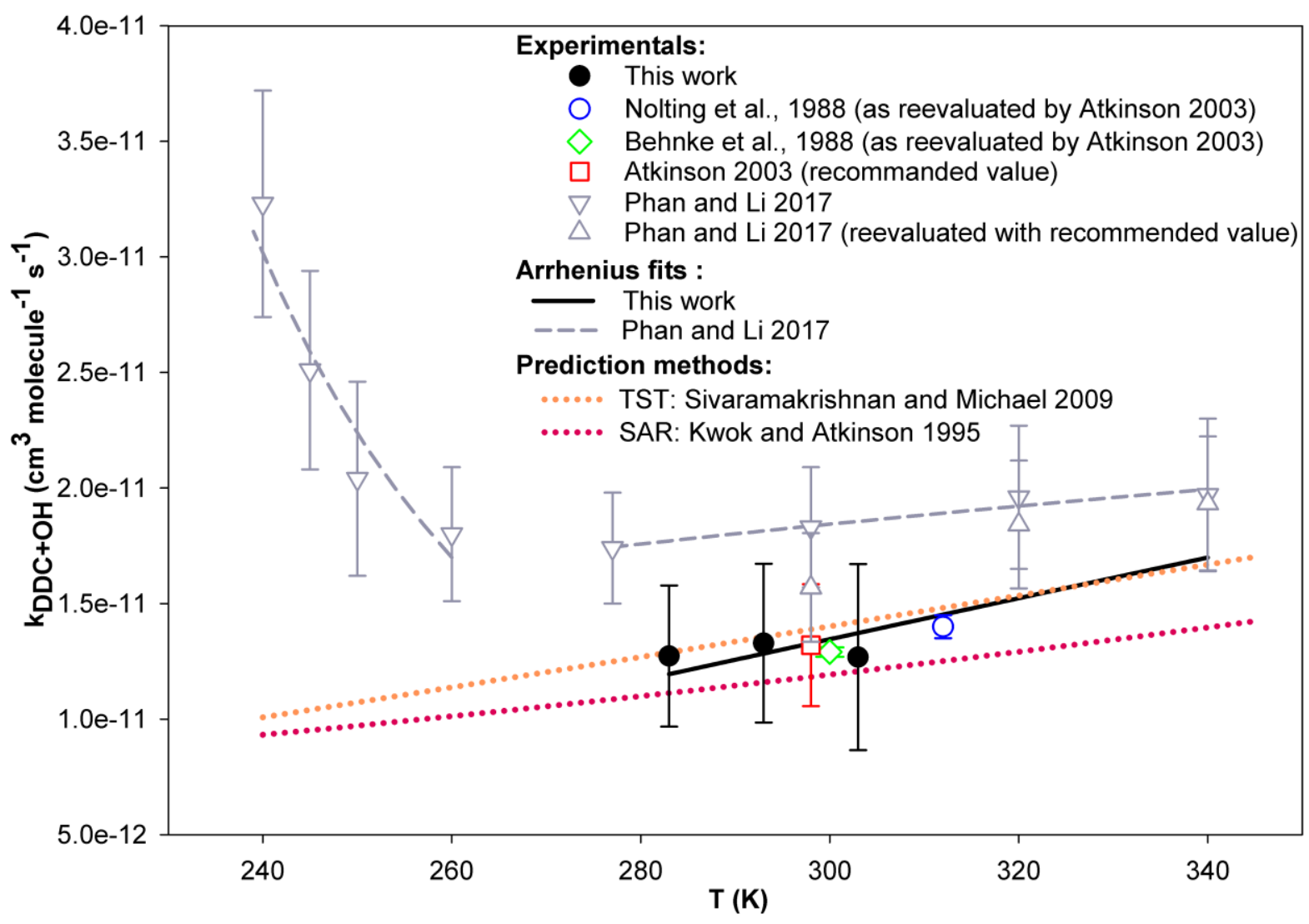

Figure 2. Reaction rate constants of $\mathrm{n}$-dodecane with $\mathrm{OH}$ radical as a function of temperature compared to the literature and prediction rate methods. 


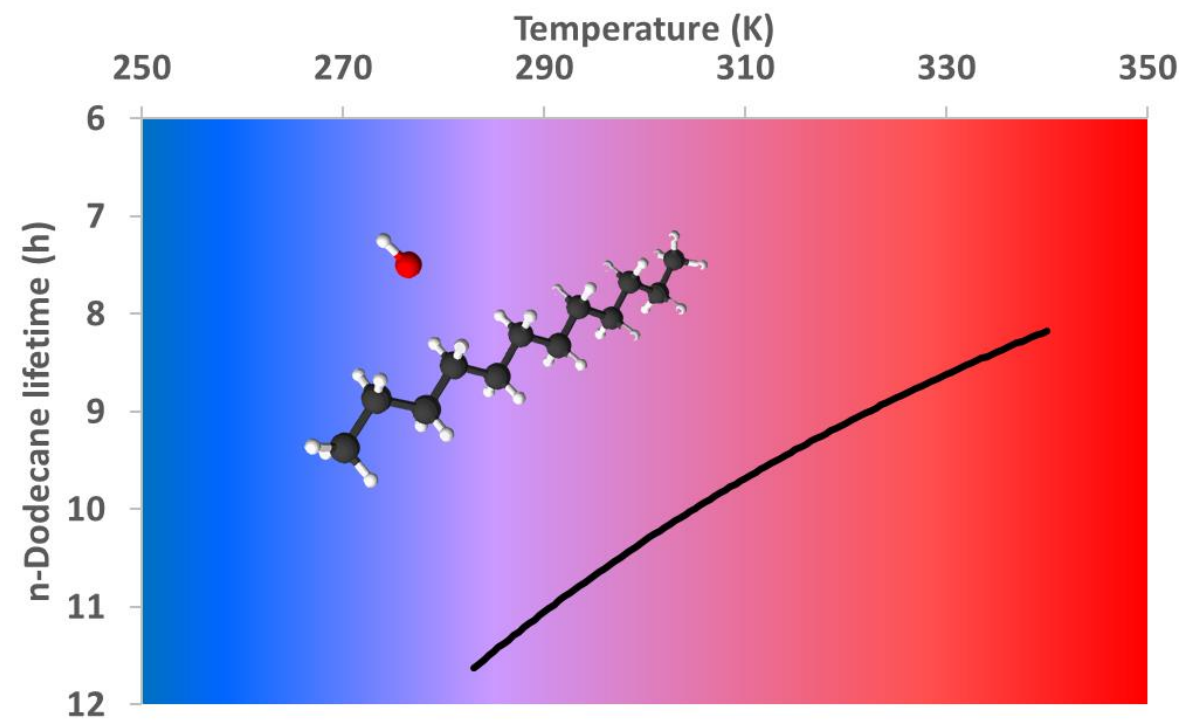

TOC graphic 